\title{
PENGARUH MODEL PEMBELAJARAN KONTEKSTUAL ADAPTIF PADA TEMA GERAK DALAM KEHIDUPAN TERHADAP KOMPETENSI IPA SISWA KELAS VIII SMPN 13 PADANG
}

\author{
Rahmi Agustia Widestra ${ }^{1)}$, Djusmaini Djamas ${ }^{2)}$, Asrizal Asrizal ${ }^{2)}$ \\ ${ }^{1)}$ Mahasiswa Pendidikan Fisika, FMIPA Universitas Negeri Padang \\ ${ }^{2)}$ Staf Pengajar Jurusan Fisika, FMIPA Universitas Negeri Padang \\ rahmiwidestra@gmail.com, asrizal_unp@yahoo.com, djusmainidjamas@yahoo.co.id
}

\begin{abstract}
In $2^{\text {st }}$ century education teaching shouls be four main principles. The main principles are teaching should be student-centered, collaborative, have context and integrated with society. The real condition in the school teaching has not done according to the demands of $21^{\text {st }}$ century education, it needs an appropriate and effective model to solve the problem. A solution of this problem is to investigate the effect of adaptive contextual teaching model of motion in life theme to improve competence of grade VIII students in science subject. This research used quasi experiment method with randomized control-group only design. The population of this research was students of grade VIII SMPN 13 Padang registered in the academic year 2017/2018. Sampling technique which used in this research was purposive sampling. The research instruments which used were observation sheet for attitude competence, written test for knowledge competence, and performance assesment skill competence. Hypothesis test used comparison test. The results of this research is the implementation of adaptive contextual teaching model gives a significant effect on the science achievement of students science competence in attitude, knowledge and skill aspect.
\end{abstract}

Keywords : Teaching Model, Contextual Teaching, Integrated Science, Competence.

\section{PENDAHULUAN}

Abad ke-21 ditandai sebagai abad keterbukaan atau abad globalisasi. Kehidupan manusia pada abad ke-21 mengalami perubahanperubahan yang fundamental dan peningkatan pemahaman terhadap suatu materi secara cepat. Abad ke-21 meminta kua litas dalam segala usaha dan hasil kerja manusia, dengan sendirinya abad ke-21 meminta Sumber Daya Manusia (SDM) yang berkualitas, memiliki kemampuan komparatif, inovatif, kompetitif, berkola boratif dan beradaptasi dengan baik sehingga mem buahkan hasil unggulan sesuai harapan abad ke-21.

Abad ke-21 juga dikenal dengan masa penge tahuan. Dalam era ini semua alternatif upaya pemenuhan kebutuhan hidup dalam berbagai kon teks lebih berbasis pengetahuan. Pendidikan abad ke21 memiliki empat prinsip pokok yaitu pembelajaran seharusnya berpusat pada siswa, kolaboratif, meme nuhi konteks dan terintegrasi dengan masyarakat ${ }^{[1]}$. Siswa harus bisa bekerja sama dengan siswa lainnya untuk mencapai tujuan pembelajaran. Pembelajaran seharusnya terkait dengan kehidupan nyata dengan dapat membantu siswa memecahkan persoalan dalam kehidupan sehari-hari di dalam masyarakat. Jadi, pembelajaran pada abad ke-21 menuntut siswa untuk lebih aktif dan menjadi pusat dalam proses pem belajaran

Berbagai cara sudah dilakukan oleh pemerintah untuk mewujudkan tujuan pendidikan serta tantangan pendidikan abad ke-21. Beberapa upaya diantaranya yaitu peningkatan kualitas pendidikan yang ditandai dengan adanya revisi atau pengembangan kurikulum pendidikan. Revisi yang terakhir kali dilakukan yaitu pengembangan Kurikulum Tingkat Satuan Pendidikan (KTSP) menjadi Kurikulum 2013 (K13). Penekanan dari K13 ini adalah peningkatan dan keseimbangan soft skill dan hard skill yang meliputi aspek kompe tensi sikap, keterampilan dan pengetahuan. Upaya lainnya yaitu Kementerian Pendidikan dan Kebudayaan mengem bangkan Gerakan Literasi Sekolah (GLS). GLS adalah upaya menyeluruh yang melibatkan semua warga sekolah dan masyarakat sebagai bagian dari ekosistem pendidikan.

Pendidikan IPA pada dasarnya memiliki tujuan mempersiapkan siswa untuk memiliki pemahaman tentang IPA dan teknologi melalui pengembangan pengetahuan, sikap dan keterampilan sehingga dapat memahami dan memecahkan permasalahan lingkungan yang ada dikehidupan nyata. Pemahaman tentang mempelajari alam sangat penting dalam kehidu pan manusia agar lebih bermakna dan bermanfaat. Melalui pendidikan IPA, kemampuan berpikir kritis, logis dan sistematis dapat dikembangkan untuk mem bekali siswa agar mampu menghadapi tantangan dalam masyarakat yang semakin kompetitif.

Kurikulum 2013 menuntut pembelajaran IPA dilaksanakan secara terpadu. Konsep keterpaduan ditunjukkan pada penyajian materi IPA yang dikemas kedalam tema tertentu yang membahas perpaduan materi-materi Fisika, Biologi, dan Kimia yang saling memiliki keterkaitan ${ }^{[2]}$. Makna terpadu dalam pembe 
lajaran IPA adalah adanya keterkaitan berbagai aspek dan materi yang tertuang dalam kompetensi dasar IPA yang melahirkan satu atau beberapa tema pembe lajaran. Keterpaduan dalam pembelajaran IPA dimak sudkan agar pembelajaran IPA terpadu lebih ber makna, efektif, dan efisien. Siswa terlatih untuk menemukan sendiri berbagai konsep yang dipelajari secara menyeluruh, bermakna, autentik, aktif, kreatif dan didukung dengan sumber belajar yang diguna kan. Keterpaduan dalam penyajian pembelajaran IPA diharapkan dapat meningkatkan kompetensi peserta didik secara menyeluruh

Pelaksanaan pembelajaran IPA terpadu dapat dilakukan dengan menggunakan beberapa tipe pembe lajaran. Salah satu tipe yang layak dikembangkan dan mudah dilaksanakan pada jenjang pendidi kan formal adalah tipe webbed atau tipe terjaring. Tipe terjaring dimulai dengan menentukan tema tertentu yang men cakup materi pembelajaran. Tema dikembangkan menjadi sub tema kemudian dikembangkan melalui aktivitas belajar yang harus dilaku kan siswa ${ }^{[3]}$

Untuk mengetahui kenyataan di sekolah dilakukan studi awal. Ada empat studi awal yang telah dilakukan. Pertama, melakukan wawancara dengan guru IPA SMPN 13 Padang. Kedua, menganalisis keterpaduan dari sepuluh buku ajar. Ketiga, menganalisis kemampuan literasi siswa dengan menggunakan instrumen berupa lembar tes literasi. Terakhir menganalisis nilai UAS IPA siswa kelas VIII SMPN 13 Padang.

Dari studi awal yang telah dilakukan dapat di kemukakan empat hasil. Pertama, pembelajaran IPA terpadu bagus untuk dilaksanakan, namun dalam pe laksanaanya masih belum semestinya karena guru masih mengajar sesuai dengan bidang ajarnya masing -masing. (GLS) sudah di terapkan namun belum optimal. Kedua, tingkat keterpaduan dari sepuluh buku ajar yang dianalisis adalah sebesar 45,58. Nilai ini menunjukkan bahwa keterpaduan dalam buku ajar masih kurang. Ketiga, kemampuan literasi siswa ma sih dikategori kan rendah yaitu 34,43. Keempat, nilai UAS siswa Kelas VIII Tahun Ajaran 2016/2017 SMPN 13 Padang belum mencapai Kriteria Ketunta san Minimal (KKM) yang ditentukan sekolah.

Kondisi nyata yang ditemukan tidak sesuai dengan kondisi ideal yang diharapkan sehingga menyebabkan masalah dalam pencapaian kompetensi siswa. Salah satu solusi untuk mengatasi adalah dengan menerapkan model pembelajaran yang diperkirakan sesuai dengan pembelaja ran IPA yaitu Model Pembelajaran Kontekstual Adaptif (MPKA).

Pembelajaran kontekstual yaitu konsep belajar yang membantu guru mengaitkan antara materi yang diajarkannya dengan situasi nyata siswa. Siswa dapat menghubungkan pengetahuan yang dimilikinya dengan penerapan dalam kehidupan mereka seharihari. Pembelajaran kontekstual, siswa akan berlatih menghubungkan apa yang diperoleh di kelas dengan kehidupan dunia nyata yang ada di sekelilingnya sehingga siswa diharapkan dapat menyadari bahwa apa yang mereka pelajari sangat berguna bagi kehidupannya ${ }^{[4]}$. Tujuan pembelajaran kontekstual ini adalah memberi pembekalan pada siswa tidak hanya teori saja namun dikaitkan dengan dunia nyata yang dekat dengan siswa ${ }^{[5]}$.

Pelaksanaan pembelajaran di kelas dilaksanakan dengan menggunakan suatu model pembelajaran. Model pembelajaran merupakan suatu kerangka konseptual yang melukiskan langkah-langkah Sistema tik dalam mengorganisasikan pengalaman belajar untuk mencapai tujuan belajar tertentu dan berfungsi sebagai pedoman bagi perancang pembelajaran dan guru dalam merancang dan melaksanakan pembelajaran ${ }^{[6]}$. Langkah-langkah yang ada di dalam model pembelajan akan dapat membantu pelaksanaan pembelajaran menjadi lebih baik, runtut dan terarah.

Model pembelajaran kontekstual adaptif (MPKA) adalah kombinasi antara model belajar dan pembelajaran kontekstual. MPKA adalah kerangka konseptual yang melukiskan prosedur yang sistematis dalam mengorganisasikan pengalaman belajar untuk mencapai tujuan belajar tertentu, dan berfungsi sebagai pedoman bagi pendidik dalam merencanakan dan melaksanakan kegiatan pembelajaran yang mampu menghubungkan materi pembelajaran dengan situasi dunia nyata siswa. Guru harus bisa mengarah kan siswa untuk mengkaitkan materi pembelajaran dengan permasalahan dunia nyata sehingga setiap siswa mendapatkan pengalaman belajar yang berkesan dan mudah dipahami sesuai dengan tujuan pembe lajaran yang akan dicapai. Model ini juga dapat menjadi pedoman bagi guru untuk pembelajaran yang lebih terarah dan runtut ${ }^{[7]}$. MPKA lebih menekankan pada konstruksi pengetahuan dengan menghubung kan materi pembelajaran yang dibahas dengan situasi nyata siswa ${ }^{[8]}$

Adanya keterkaitan materi pembelajaran dengan situasi dunia nyata inilah yang menjadi ciri khas dari MPKA. Secara umum, ada enam karakteris tik dari MPKA. 1) pembelajaran dikaitkan dengan konteks dunia nyata, (2) pembelajaran berpusat pada siswa, (3) pembelajaran memberikan tugas bermakna kepada siswa, (4) pelajaran memberikan pengalaman bermakna, (5) pembelajaran mendorong peningkatan literasi siswa. dan (6) pembelajaran mendorong kerja kolaboratif. Hal ini sejalan dengan tuntutan pembe lajaran abad ke-21.

MPKA ini memiliki keunggulan dan kekurang an didalamnya. Keunggulan dalam MPKA ini yaitu : 1) materi pembelajaran dikaitkan dengan situasi dunia nyata, 2) sesuai dengan pembelajaran IPA terpadu, 3) pembelajaran mendorong proses sains, 4) tingkat keterlibatan aktif siswa tinggi dalam proses pembela jaran, 5) pembelajaran menumbuhkan dan mengem bangkan literasi era digital pada siswa. Kekurangan dari model ini yaitu, 1) adanya kesulitan dalam mengubah kebiasaan belajar siswa, 2) adanya keter batasan alat eksperimen untuk mendukung proses penyelidikan siswa, 3) adanya kesulitan dalam 
mengatur penerapan situasi saintifik dalam kehidupan sehari-hari, 4) kesulitan dalam mengelola tugas-tugas siswa dalam pembelajaran. Kelemahan ini akan bisa diatasi ketika guru dapat menguasai model dengan baik dan menguasai materi yang diajarkan.

Tema yang digunakan dalam penelitian ini adalah tema gerak dalam kehidupan. Tema ini memiliki empat sub tema didalamnya. Keempat sub tema itu yaitu gaya dalam kehidupan, gerak dan usaha dalam kehidupan, gerak tumbuhan dan hewan serta gerak pada manusia.

Gerak merupakan salah satu ciri makhluk hidup untuk melaksanakan kegiatan hidupnya. Gerak dapat terjadi karena adanya pengaruh rangsangan (stimulus) ${ }^{[9]}$. Rangsangan dapat berupa tarikan atau dorongan yang sering disebut dengan gaya. Gaya adalah tarikan atau dorongan sebuah benda yang membuat benda berubah posisi dan memiliki arah ${ }^{[10]}$. Sistem gerak tidak hanya ada pada manusia namun juga pada tumbuhan dan hewan. Sistem gerak pada manusia terdiri dari otot dari rangka dan otot. Rangka merupakan alat gerak pasif sedangkan otot merupakan alat gerak aktif. Otot melekat pada rangka yang akan menggerakkan rangka. Gerak pada tumbuhan bersifat pasif, artinya tidak memerlukan adanya pindah tempat. Gerak pada tumbuhan terbagi menjadi tiga yaitu gerak endonom, esionom, dan higroskopis. Gerak endonom gerak yang tidak diketahui penyebab luarnya. Gerak esionom adalah gerak tumbuhan yang disebabkan oleh adanya rangsangan dari lingkungan. Gerak Higroskopis adalah gerak bagian tubuh tumbuhan karena pengaruh perubahan kadar air di dalam sel sehingga terjadi pengerutan yang tidak merata. Gerak hewan dibedakan menjadi hewan air, hewan darat dan hewan udara ${ }^{[11]}$.

MPKA telah dikembangkan oleh Asrizal ${ }^{[8]}$. Pelaksanaan penelitian baru sampai pada tahap uji coba untuk validitas, kepraktisan dan efektivitas dari MPKA ini saja. Peneliti tertarik untuk melanjutkan penelitian ini pada tahap coba lapangan sebagai bagian dari penelitian induk.

Penelitian dilakukan memiliki tujuan yang ingin dicapai. Tujuan dapat menjadi arahan dalam melakukan suatu penelitian, sehingga penelitian dapat berjalan sesuai harapan. Tujuan dalam penelitian ini adalah menyelidiki pengaruh model pembelajaran kontekstual adaptif pada tema gerak dalam kehidupan terhadap pencapaian kompetensi IPA siswa kelas VIII SMPN 13 Padang.

\section{METODE PENELITIAN}

Penelitian ini dilaksanakan pada Semester I Kelas VIII SMPN 13 Padang yang beralamat di Jl. Lapangan Bola, Tabing Kota Padang Tahun Ajaran 2017/2018. Penelitian ini dilaksanakan pada bulan Agustus - Desember 2017. Penelitian ini termasuk jenis penelitian eksperimen semu. Tujuan dari peneli tian eksperimen semu adalah untuk memperoleh infor masi yang merupakan perkiraan bagi informasi dalam keadaan yang tidak memungkinkan untuk mengontrol atau memanipulasi semua variabel yang relevan. Desain penelitian yang digunakan adalah rancangan kelompok kontrol ternormalisasi. Adapun desain penelitiannya yaitu :

Tabel 1. Desain Penelitian Kelompok Kontrol Ternormalisasi

\begin{tabular}{|c|c|c|}
\hline Group & Treatment & Posttest \\
\hline Eksperimen & $\mathrm{X}$ & $\mathrm{T}$ \\
\hline Kontrol & - & $\mathrm{T}$ \\
\hline Dengan : \\
$\mathrm{X}=$ Pembelajaran menggunakan model pem- \\
belajaran kontekstual adaptif. \\
$\mathrm{T}=\begin{array}{l}\text { Post test yang dilakukan pada kelas } \\
\text { eksperimen dan kelas kontrol }\end{array}$
\end{tabular}

Variabel penelitian adalah segala sesuatu yang yang berbentuk apa saja yang ditetapkan oleh peneliti untuk diamati sehingga diperoleh informasi yang dibutuhkan oleh peneliti, kemudian ditarik kesim pulannya Variabel dalam penelitian ini ada tiga yaitu variabel bebas, variabel terikat dan variabel kontrol. Variabel bebas penelitian ini adalah Model Pembe lajaran Kontekstual Adaptif. Variabel terikatnya adalah kom petensi IPA siswa kelas VIII SMPN 13 Padang. Variabel kontrolnya 1) materi yang diguna kan sama, sesuai dengan Kurikulum 2013, 2) kemam puan awal siswa antara kedua kelas sama, 3) guru, waktu yang digunakan adalah sama dan 4) jumlah dan jenis soal yang diujikan pada kedua kelas adalah sama.

Populasi dalam penelitian ini adalah seluruh siswa kelas VIII SMPN 13 Padang yang seluruhnya berjumlah 7 (tujuh) kelas. Masing-masing kelas terdiri dari 31-33 siswa perkelas sehingga populasi berjum lah 224 siswa. Pengambilan sampel dalam penelitian ini dilakukan secara sampel bertujuan, yaitu peng ambilan sampel berdasarkan alasan-alasan khusus atau tujuan tertentu dalam penelitian.

Sampel diambil menggunakan beberapa lang kah-langkah meliputi mengumpulkan data ujian akhir semester IPA siswa kelas VIII semester Januari-Junli 2017 dari seluruh kelas populasi Kemudian di tentukan kelas sampel sebelum diberi perlakuan seba nyak 2 kelas dari jumlah populasi. Terlebih dahulu dilihat kemampuan awal dari kedua kelas sampel, apakah kedua sampel memiliki kemampuan awal yang sama. Kemampuan awal ini dapat dilihat dengan melakukan uji perbedaan dua rata-rata yang sebelum nya sudah dianalisis normalitas dan homogenitas dari data tersebut.

Penelitian ini memiliki tiga tahapan dalam pelaksanaannya yaitu tahap persiapan, tahap pelaksana an dan tahap penyelesaian. Tahap persiapan dimulai dari menentukan jadwal, menentukan sampel, persiap an perangkat pembelajaran yang akan digunakan hingga instrumen penelitian yang akan dipakai 
selama penelitian. Tahap pelaksanaan yaitu melaksanakan penelitian skenario pembelajaran harus telah siap dan digunakan sebagai pedoman dalam pene litian. Tahap penyelesaian yaitu peneliti memberikan post test untuk kompetensi pengetahuan pada kedua kelas sampel dan mengumpulkan data yang dibutuhkan untuk kompetensi sikap dan keterampilan yang telah dinilai selama proses pelaksanaan pembelajaran

Penilaian kompetensi sikap menggunakan instrumen observasi yang memuat aspek-aspek yang diamati dari sikap siswa selama proses pembelajaran berlangsung. Ada enam aspek penilaian pada kom petensi sikap yaitu ingin tahu, percaya diri, disiplin, komitmen inkuiri, kerja sama dan komunikasi. Aspek tersebut ditafsirkan berupa skor atau angka.

Instrumen dalam kompetensi pengetahuan adalah tes tulis yang dilaksanakan di akhir penelitian berupa pilihan ganda. Agar tes ini menjadi alah ukur yang baik maka hal pertama yang harus dilakukan yaitu membuat kisi-kisi soal uji coba. Setelah itu dibuat soal uji coba berdasarkan kisi-kisi yang telah dibuat sebanyak 90 soal. Langkah selanjutnya adalah dengan melakukan uji coba soal yang dilakukan di beberapa sekolah yaitu SMPN 1 Padang, SMPN 13 Padang dan SMPN 15 Padang. Hal terakhir yang dilakukan yaitu menganalisis soal uji coba yang telah dilaksanakan untuk dilihat validitas, tingkat kesukaran dan daya beda soal serta nilai reliabilitas soal uji coba sehingga didapatkan soal post test yang bisa digunakan sebagi parameter dalam mengukur kompetensi pengetahuan.

Penilaian keterampilan ini dilakukan di saat siswa melakukan kegiatan praktikum di laboratorium. Instrumen yang digunakan berupa skala pe nilaian. Penilaian kinerja yang menggunakan skala penilaian memungkinkan penilaian memberi nilai tengah terhadap penguasaan kompetensi tertentu, karena pemberian nilai secara kontinu dimana pilihan kategori nilai lebih dari dua. Skala penilaian terentang dari tidak sempurna sampai sangat sempurna. Rentangan skala ini sesuai dengan indikator penilaian yang ada pada instrument penilaian.

Analisis data penelitian dilakukan untuk menguji kebenaran hipotesis yang diajukan dalam penelitian. Analisis yang dilakukan melalui beberapa tahapan yaitu analisis deskriptif, tahap persentase, tahap uji persyaratan dan tahap uji hipotesis. Hasil akhir analisis data berupa kesimpulan dari penelitian yang telah dilakukan.

Statistik deskriptif adalah statistik yang ber fungsi untuk mendeskripsikan atau memberikan gam baran terhadap objek yang diteliti melalui data sampel atau populasi sebagaimana adanya dan berlaku untuk umum. Pada statistik deskriptif ini, akan menyajikan data melalui tabel, grafik, perhitungan mean, median, modus, dan variasi kelompok melalui rentang data.
Data penelitian yang berupa hasil belajar siswa diuji apakah berasal dari populasi yang sebarannya normal, perlu dilakukan uji normalitas. Uji ini perlu dilakukan karena semua perhitungan statistic parametrik memiliki asumsi sebaran normali tas. Uji normalitas ini menggunakan uji Liliefors dengan mengambil harga yang paling besar diantara harga mutlak data selisih yang disebut $L_{0}$, membandingkan nilai $\mathrm{L}_{\mathrm{o}}$ dengan nilai kritis $\mathrm{L}_{\mathrm{t}}$ yang terdapat dalam tabel nilai kritis L untuk uji Liliefors pada taraf nyata $\alpha=0,05$. Kriteria data terditribusi normal jika $\mathrm{L}_{\mathrm{o}}<\mathrm{L}_{\mathrm{t}}$.

Kemudian setelah itu dilakukan uji homoge nitas. Uji ini bertujuan untuk melihat apakah kedua kelompok data mempunyai varians yang homogen atau tidak. Uji ini dilakukan dengan cara uji dua variansi yang dikenal dengan uji perbedaan dua variansi atau uji $\mathrm{F}$ dengan menggunakan rumus:

$$
\mathrm{F}=\frac{S_{1}^{2}}{S_{2}^{2}}
$$

Keterangan:

$\mathrm{F} \quad=$ Varians kelompok total

$\mathrm{S}_{1}{ }^{2}=$ Varians hasil belajar tertinggi

$\mathrm{S}_{2}{ }^{2}=$ Varians hasil belajar terrendah

Jika sudah didapat, maka dibandingkan $\mathrm{F}$ hitung $(\mathrm{Fh})$ dengan harga $\mathrm{F}$ total $(\mathrm{Ft})$. Menurut tabel jika $\mathrm{Fh}<\mathrm{Ft}$, maka kedua kelompok data mempunyai varians yang homogen dan sebaliknya

Setelah itu dilakukan uji perbedaan dua ratarata untuk menguji hipotesis yang diajukan. Jika data dalam penelitian ini terdistribusi normal dan me miliki variansi yang homogen untuk kompetensi sikap, kompetensi pengetahuan dan keterampilan maka di gunakan uji t, karena $\sigma_{1}=\sigma_{2}=\sigma$ sedangkan $\sigma$ tidak diketahui harganya. Rumus uji t dalam yaitu.

$t=\frac{\overline{X_{1}}-\overline{X_{2}}}{S \sqrt{\frac{1}{n_{1}}+\frac{1}{n_{2}}}}$ dengan $S^{2}=\frac{\left(n_{1}-1\right) S_{1}{ }^{2}+\left(n_{2}-1\right) S_{2}{ }^{2}}{n_{1}+n_{2}-2}$

Keterangan:

$\mathrm{X}_{1}=$ Nilai rata-rata kelas eksperimen

$\mathrm{X}_{2}=$ Nilai rata-rata kelas kontrol

$\mathrm{S}_{1}^{2}=$ Varians kelas eksperimen

$\mathrm{S}_{2}^{2}=$ Varians kelas kontrol

$\mathrm{S}^{2}=$ Varians gabungan

$\mathrm{n}_{1}=$ Jumlah siswa kelas eksperimen

$\mathrm{n}_{2}=$ Jumlah siswa kelas kontrol

Harga $t_{\text {hitung }}$ dibandingkan dengan $t_{\text {tabel }}$ yang terdapat dalam tabel distribusi t. Kriteria pengujian adalah terima Ho jika digunakan uji 2 pihak pada taraf signifikan 0,05 sedangkan untuk harga lainnya Ho ditolak dan $\mathrm{H}_{\mathrm{i}}$ diterima

\section{HASIL PENELITIAN DAN PEMBAHASAN}

\section{Hasil Penelitian}

Hasil peneltian pertama adalah pengaruh penerapan MPKA terhadap kompetensi sikap siswa. Hasil penilaian kompetensi sikap IPA siswa 
diperoleh selama proses belajar IPA berlangsung dalam bentuk deskripsi data sikap.

Tabel 2. Data Nilai Rata-Rata Kompetensi Sikap Siswa Kelas Ekperimen dan Kelas Kontrol

\begin{tabular}{|l|c|c|c|c|c|c|c|}
\hline \multicolumn{1}{|c|}{ Kelas } & IT & PD & DS & KI & KS & KM & $\begin{array}{c}\text { Rata- } \\
\text { Rata }\end{array}$ \\
\hline Eksperimen & 79 & 79 & 86 & 78 & 80 & 80 & 81 \\
\hline Kontrol & 73 & 68 & 69 & 68 & 73 & 71 & 70 \\
\hline
\end{tabular}

Rata-rata kelas eksperimen lebih tinggi daripada kelas kontrol. Namun pada data tersebut belum dapat mem perlihatkan apakah terdapat pengaruh yang berarti pada kedua kelas sampel. Data kompetensi sikap diolah menggunakan uji normalitas dan uji homo genitas untuk menentukan uji hipotesis yang diguna kan. Hasil uji normalitas dapat dideskripsikan seperti pada Tabel 3.

Tabel 3. Hasil Uji Normalitas Kompetensi Sikap Kelas Eksperimen dan Kelas Kontrol

\begin{tabular}{|l|c|c|c|c|c|}
\hline \multicolumn{1}{|c|}{ Kelas } & $\mathrm{N}$ & $\alpha$ & Lo & Lt & Ket \\
\hline Eksperimen & 32 & \multirow{2}{*}{0,05} & 0.072 & 0.15662 & Normal \\
\cline { 1 - 3 } \cline { 5 - 6 } Kontrol & 32 & & 0.076 & 0.15662 & Normal \\
\hline
\end{tabular}

Hasil uji normalitas kelas sampel menunjukkan bahwa kelas eksperimen dan kelas kontrol memiliki harga Lo<Lt pada taraf nyata 0,05. Data masingmasing kelas sampel pada kompetensi sikap terdistribusi normal. Data uji homogenitas dijelaskan pada Tabel 4.

Tabel 4. Hasil Uji Homogenitas Kompetensi Sikap Kelas eksperimen dan kelas Kontrol

\begin{tabular}{|l|c|c|c|c|c|}
\hline \multicolumn{1}{|c|}{ Kelas } & $\mathrm{S}$ & $\mathrm{S}^{2}$ & $\mathrm{Fh}$ & $\mathrm{Ft}$ & Ket \\
\cline { 1 - 4 } Eksperimen & 3.302 & 10.9 & \multirow{2}{*}{0,95} & \multirow{2}{*}{1,82} & Homogen \\
\hline Kontrol & 3.379 & 11.42 & & & \\
\hline
\end{tabular}

Hasil uji homogenitas kedua kelas sampel diperoleh $\mathrm{Fh}=0,95$ dan $\mathrm{Ft}=1,82$ dengan taraf nyata 0,05 , dan derajat kebebasan 31 adalah 1,82. Hasil uji menunjukkan bahwa $\mathrm{Fh}<\mathrm{Ft}$, artinya data kedua kelas sampel berasal dari populasi yang memiliki varians yang homogen.

Setelah dilakukan uji normalitas dan homoge nitas didapatkan kedua data terdistribusi normal dan variansi yang homogen, sehingga di-lakukan uji hipotesis perbedaan dua rata-rata (uji t). hasil uji $t$ dapat terlihat pada Tabel 5.

Tabel 5. Hasil Uji t Kompetensi Sikap Kelas Eksperimen dan Kelas Kontrol

\begin{tabular}{|l|c|c|c|c|}
\hline \multicolumn{1}{|c|}{ Kelas } & $\bar{x}$ & $\mathrm{~S}^{2}$ & thitung & ttabel \\
\hline Eksperimen & 80.78 & 10.9 & \multirow{2}{*}{12,69} & \multirow{2}{*}{2,00} \\
\cline { 1 - 3 } Kontrol & 70.18 & 11.42 & & \\
\hline
\end{tabular}

Hasil uji t menunjukkan bahwa daerah penerimaan Ho untuk taraf nyata $(\alpha) 0,05$ diperoleh $t_{\text {tabel }}=2,00$. Hasil perhitungan nilai t yang diperoleh 12,69 . Hasil perhitungan $\mathrm{t}$ berada di luar daerah penerimaan Ho, maka Hi diterima. Kurva penerimaan dan penolakan Ho dapat dilihat pada Gambar 2.

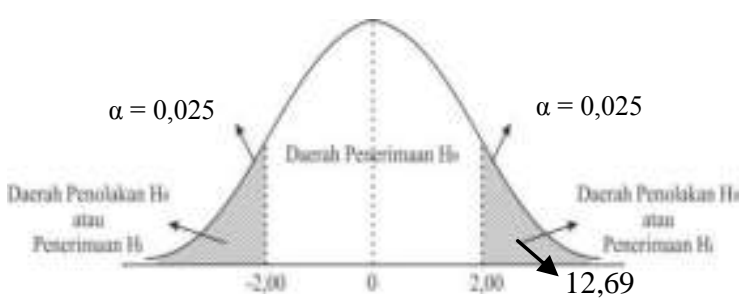

Gambar 2. Kurva Penerimaan dan Penolakan $\mathrm{H}_{\mathrm{o}}$ pada Kompetensi Sikap

Kurva Penerimaan Ho dan penolakan Hi kompetensi pengetahuan memperlihatkan bahwa $t_{\text {hitung }}$ berada di luar daerah penerimaan Ho. Hal ini menunjukkan bahwa Hi diterima pada taraf nyata 0,05 . Kesimpulan yang didapatkan dari uji hipotesis adalah terdapat pengaruh yang berarti dari penerapan model pembe lajaran kontekstual adaptif pada kompetensi penge tahuan siswa.

Hasil penelitian kedua adalah pengaruh penera pan MPKA terhadap kompetensi pengetahuan siswa. Hasil penilaian kompetensi pengetahuan didapatkan dari post test. Deskripsi data hasil penilaian kompe tensi pengetahuan siswa dapat dilihat pada Tabel 6 .

Tabel 6. Deskripsi Data Kompetensi Pengetahuan Kelas Eksperimen dan Kelas Kontrol

\begin{tabular}{|l|c|c|c|c|c|}
\hline \multicolumn{1}{|c|}{ Kelas } & $\begin{array}{c}\text { Ter- } \\
\text { tinggi }\end{array}$ & $\begin{array}{c}\text { Ter- } \\
\text { rendah }\end{array}$ & $\begin{array}{c}\text { Rata- } \\
\text { Rata }\end{array}$ & $\mathrm{S}^{2}$ & $\mathrm{~S}$ \\
\hline Eksperimen & 87.5 & 47.5 & 66,0 & 118.08 & 10.86 \\
\hline Kontrol & 35,0 & 67.5 & 49.6 & 78.67 & 8.87 \\
\hline
\end{tabular}

Rata-rata kelas eksperimen lebih tinggi daripada kelas kontrol. Selisih rata-rata kedua kelas juga signifikan yaitu sebesar 16,4. Data ini belum memperlihatkan pengaruh yang berarti. Data kompetensi pengetahuan diolah menggunakan uji normalitas dan uji homogenitas untuk menentukan uji hipotesis yang digunakan. Hasil uji normalitas dapat dideskripsikan seperti pada Tabel 7.

Tabel 7. Hasil Uji Normalitas Kompetensi Penge tahuan Kelas Eksperimen dan Kelas Kontrol

\begin{tabular}{|c|c|c|c|c|c|}
\hline Kelas & $\mathrm{N}$ & A & Lo & $\mathrm{Lt}$ & Ket \\
\hline Eksperimen & 32 & \multirow{2}{*}{0,05} & 0.0791 & 0.157 & Normal \\
\hline Kontrol & 32 & & 0.105 & 0.157 & Normal \\
\hline
\end{tabular}

Kelas eksperimen dan kelas kontrol memiliki harga Lo $<$ Lt pada taraf nyata 0,05 . Data masing-masing kelas sampel pada kompetensi pengetahuan terdis tribusi normal. Setelah itu diuji apakah variansi kedua sampel homogen atau tidak. Hal ini berguna untuk menentukan uji perbedaan dua rata-rata yang harus dilakukan untuk membuktikan hipotesis yang ada. 
Tabel 8. Hasil Uji Homogenitas Kompetensi Pengetahuan Kelas Eksperimen dan Kelas Kontrol

\begin{tabular}{|l|c|c|c|c|c|}
\hline \multicolumn{1}{|c|}{ Kelas } & $\mathrm{S}$ & $\mathrm{S}^{2}$ & $\mathrm{Fh}$ & $\mathrm{Ft}$ & Ket \\
\cline { 1 - 3 } Eksperimen & 10.87 & 118.09 & \multirow{2}{*}{1,50} & \multirow{2}{*}{1,82} & Homogen \\
\cline { 1 - 3 } Kontrol & 8.87 & 78.67 & & & \\
\hline
\end{tabular}

Hasil uji homogenitas kedua kelas sampel diperoleh $\mathrm{Fh}=1,50$ dan $\mathrm{Ft}=1,82$ dengan taraf nyata 0,05, dan derajat kebebasan 31 adalah 1,82. Hasil uji menunjukkan bahwa $\mathrm{Fh}<\mathrm{Ft}$, artinya data kedua kelas sampel berasal dari populasi yang memiliki varians yang homogen.

Setelah dilakukan uji normalitas dan homoge nitas didapatkan kedua data terdistribusi normal dan variansi yang homogen, sehingga dilakukan uji hipotesis perbedaan dua rata-rata (uji t). Hasil uji $t$ dapat terlihat pada Tabel 9.

Tabel 9. Hasil Uji t Kompetensi Pengetahuan Kelas Eksperimen dan Kelas Kontrol

\begin{tabular}{|l|c|c|c|c|c|}
\hline \multicolumn{1}{|c|}{ Kelas } & $\mathrm{N}$ & $\bar{X}$ & $\mathrm{~S}^{2}$ & thitung & ttabel \\
\hline Eksperimen & 32 & 66.02 & 118.09 & \multirow{2}{*}{6,62} & 2,00 \\
\hline Kontrol & 32 & 49.61 & 78.67 & & \\
\hline
\end{tabular}

Hasil uji t menunjukkan penerimaan Ho untuk taraf nyata $(\alpha) \quad 0,05$ didapatkan $t_{\text {tabel }}=2,00$. Hasil perhitung an nilai $\mathrm{t}$ yang diperoleh 6,62 . Hasil perhitungan $t$ berada di luar daerah penerimaan Ho, maka Hi diterima. Kurva penerimaan dan penolakan dapat di lihat pada Gambar 3.

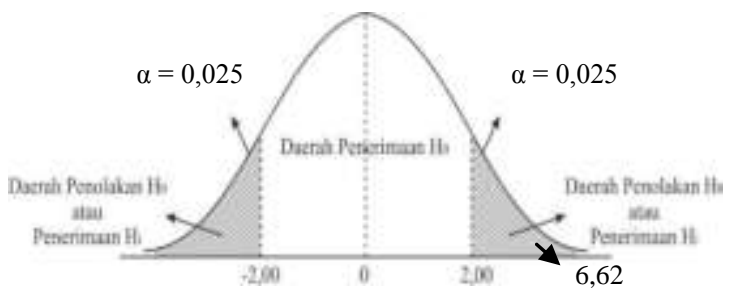

Gambar 3. Kurva Penerimaan dan Penolakan $\mathrm{H}_{\mathrm{o}}$ pada Kompetensi Pengetahuan

Kurva Penerimaan Ho dan penolakan Hi kompe tensi pengetahuan memperlihatkan bahwa $t_{h}$ berada di luar daerah penerimaan Ho. Hal ini menunjukkan bahwa Hi diterima pada taraf nyata 0,05. Dari hasil uji hipotesis dapat disimpulkan bahwa terdapat pengaruh yang berarti dengan me nerapkan model pembelajaran kontekstual adaptif terhadap pencapai an kompetensi pengetahuan siswa.

Hasil penelitian terakhir adalah pengaruh penerapan MPKA terhadap kompetensi keterampilan siswa. Hasil penilaian kompetensi keterampilan di dapatkan melalui unjuk kerja yang diperoleh melalui hasil pengamatan selama praktikum dan proses pembelajaran berlangsung. Data kompetensi keteram pilan bisa dilihat pada Tabel 10 .
Tabel 10. Data Kompetensi Keterampilan Kelas Eksperimen dan Kelas Kontrol

\begin{tabular}{|l|c|c|c|c|c|c|}
\hline \multicolumn{1}{|c|}{ Kelas } & M1 & M2 & M3 & M4 & M5 & $\begin{array}{c}\text { Rata- } \\
\text { Rata }\end{array}$ \\
\hline Eksperimen & 86.7 & 85.4 & 81.8 & 83.3 & 65.1 & 80.5 \\
\hline Kontrol & 69,0 & 61.2 & 59.6 & 59.4 & 57.3 & 70.2 \\
\hline
\end{tabular}

Rata-rata kompetensi keterampilan kelas ekperimen lebih tinggi daripada kelas kontrol, begitupun nilai tiap indikatornya. Hasil data Tabel 10 menunjukkan model pembelajaran kontekstual adaptif memiliki pengaruh terhadap pencapaian kompetensi keteram pilan siswa. Data kompetensi keterampilan diolah menggunakan uji normalitas dan uji homogenitas untuk menentukan uji hipotesis yang digunakan. Hasil uji normalitas dapat dideskripsikan pada Tabel 11.

Tabel 11.Hasil Uji Normalitas Kompetensi Keterampilan Kelas Eksperimen dan Kelas Kontrol

\begin{tabular}{|l|c|c|c|c|c|}
\hline \multicolumn{1}{|c|}{ Kelas } & $\mathrm{N}$ & $\mathrm{A}$ & Lo & Lt & Ket \\
\hline Eksperimen & 32 & \multirow{2}{*}{0,05} & 0.102 & 0,156 & Normal \\
\cline { 1 - 4 } \cline { 5 - 7 } Kontrol & 32 & & 0.146 & 0,156 & Normal \\
\hline
\end{tabular}

Kelas eksperimen dan kelas kontrol memiliki harga Lo $<$ Lt pada taraf nyata 0,05 . Data masing-masing kelas sampel pada kompetensi keterampilan terdistribusi normal.

Tabel 12. Hasil Uji Homogenitas Kompetensi Keterampilan Kelas Eksperimen dan Kelas Kontrol

\begin{tabular}{|l|c|c|c|c|c|}
\hline \multicolumn{1}{|c|}{ Kelas } & $\mathrm{S}$ & $\mathrm{S}^{2}$ & $\mathrm{Fh}$ & $\mathrm{Ft}$ & Ket \\
\hline Eksperimen & 5.31 & 28.17 & \multirow{2}{*}{0,61} & \multirow{2}{*}{1,82} & Homogen \\
\hline Kontrol & 6.78 & 45.95 & & & \\
\hline
\end{tabular}

Hasil uji homogenitas kedua kelas sampel diperoleh $\mathrm{Fh}=0,61$ dan $\mathrm{Ft}=1,82$ dengan taraf nyata 0,05 , dan derajat kebebasan 31 adalah 1,82 . Hasil uji menunjuk kan bahwa $\mathrm{Fh}<\mathrm{Ft}$, artinya data kedua kelas sampel berasal dari populasi yang memiliki varians yang homogen.

Tabel 13. Hasil Uji t Kompetensi Pengetahuan Kelas Eksperimen dan Kelas Kontrol

\begin{tabular}{|l|c|c|c|c|c|}
\hline \multicolumn{1}{|c|}{ Kelas } & $\mathrm{N}$ & $\bar{X}$ & $\mathrm{~S}^{2}$ & \multirow{2}{*}{$\mathrm{t}_{\text {hitung }}$} & \multirow{2}{*}{$\mathrm{t}_{\text {tabel }}$} \\
\hline Eksperimen & 32 & 80.47 & 61.05 & \multirow{2}{*}{12,76} & \multirow{2}{*}{2,00} \\
\hline Kontrol & 32 & 28,167 & 45,945 & & \\
\hline
\end{tabular}

Hasil Uji t menunjukkan bahwa daerah penerimaan Ho untuk taraf nyata $(\alpha) 0,05$ didapatkan $t_{\text {tabel }}=2,00$ berarti nilai $\mathrm{t}$ berada di luar daerah penerimaan Ho, maka Hi diterima. Kesimpulan yang didapatkan dari uji hipotesis adalah terdapat pengaruh yang berarti pada kompetensi keterampilan setelah diterapkan model pembelajaran kontekstual adaptif.

Kurva penerimaan Ho dan penolakan Hi dapat dilihat pada Gambar 4. 


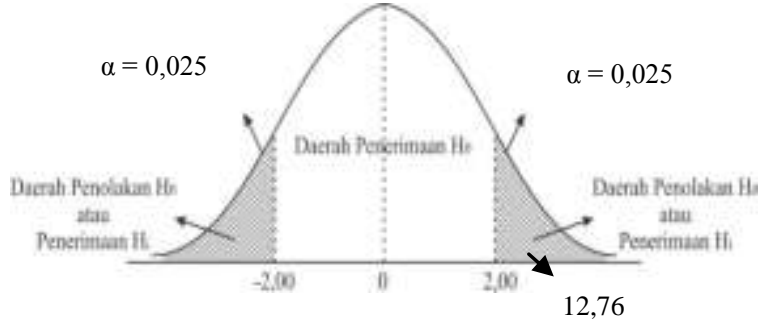

Gambar 4. Kurva Penerimaan dan Penolakan Ho pada Kompetensi keterampilan

Kurva Penerimaan Ho dan penolakan $\mathrm{Hi}$ kompetensi keterampilan memperlihatkan bahwa $t_{\text {hitung }}$ berada di luar daerah penerimaan Ho. Gambar 4 menunjukkan bahwa nilai Hi diterima pada taraf nyata 0,05 , berarti terdapat pengaruh yang berarti penerapan model pembelajaran konteks tual adaptif pada kompetensi keterampilan siswa.

\section{Pembahasan}

Hasil pertama yang dicapai yaitu penerapan MPKA meningkatkan kompetensi sikap siswa. Peningkatan pada kompetensi sikap ini meliputi aspek ingin tahu, percaya diri, disiplin, komitmen inkuiri, kerjasama dan komunikasi memiliki yang menjadi lebih baik. Peningkatan ini menyatakan bahwa MPKA dapat dijadikan suatu model yang baik dalam proses pembelajaran dalam kompetensi sikap.

MPKA dapat meningkatkan kompetensi sikap karena pertama, pembelajaran yang berpusat kepada siswa, maksudnya siswa tidak hanya mendapatkan informasi dari guru saja akan tetapi siswa juga mencari informasi pembelajaran melalui sumbersumber lain berupa buku bacaan yang nantinya akan diambil kesimpulannya. Selama pembelajaran juga dilakukan dalam kelompok yang mengharuskan siswa untuk dapat bekerjasama dan berkomunikasi dengan baik. Semakin sering mereka bekerjasama dan ber komunikasi semakin bagus pula kompetensi sikap siswa tersebut. Kedua, karena pembelajaran itu ber pusat pada siswa dan proses pembelajaran yang digunakan adalah kontekstual adaptif maka sumbersumber belajar tidak hanya saja dari buku namun dari kehidupan nyata yang bisa ia kaitkan dan diterapkan dalam kehidupan sehari-harinya yang akan mem bentuk sikap berpikir kritis dan memiliki ingin tahu yang tinggi. Peningkatan sikap ini akan meningkat dengan adanya tugas-tugas kontekstual berupa kegiatan menerapkan yang lebih kepada bagaimana cara yang akan diambil siswa dapat mengkoreasikan materi pembelajaran dengan dunia nyata disekitarnya sesuai dengan kondisi dan kemampuan siswa. MPKA pada kompetensi sikap menjawab salah satu tantangan pendidikan abad 21 yaitu pembelajaran seharusnya berpusat pada siswa ${ }^{[1]}$

Hasil kedua yang dicapai adalah penerapan MPKA meningkatkan kompetensi pengetahuan siswa. Nilai post test yang didapatkan lebih meningkat. Pemahaman siswa akan pelajaran menjadi lebih baik.
MPKA dapat meningkatkan kompetensi pengetahuan IPA siswa karena sintak pada MPKA mengandung pembelajaran bermakna, pembelajaran kontekstual, dan teori konstruktivisme. Pembelajaran IPA Terpadu mendukung kerangka pengembangan kurikulum 2013 yang mengaitkan IPA dalam kehidu pan sehari hari. Siswa dilatih untuk mengem bangkan kompetensinya dengan mengkonstruksi kompetensi secara aktif dan bermakna. Pembelajaran ini relevan dengan salah satu prinsip essensial dari pembelajaran abad ke-21 yaitu pembelajaran seharusnya kontekstual ${ }^{[12]}$. Pembelajaran kontekstual konsep belajar yang membantu guru mengaitkan antara materi yang diajarkannya dengan situasi nyata peserta didik membuat hubungan antara pengetahuan yang dimilikinya dengan penerapan dalam kehidupan mereka sehari-hari ${ }^{[13]}$. Pembelajaran kontekstual ini akan memudahkan siswa untuk mengingat pem belajaran dengan mengeksplorasi pengetahuan nya karena dekat dengan lingkungan sekitarnya seharihari. Guru akan memudahkan siswa memahami de ngan memberikan contoh langsung yang berkaitan dengan dunia nyata. Hal ini terkandung dalam lang kah-langkah dari MPKA itu sendiri yaitu siswa mengeksplorsi dunia nyata yang relevan dengan materi kemudian guru akan menjelaskan konteks dunia nyata yang relevan dengan materi pembelajaran.

Teori konstruktivisme akan membantu siswa untuk dapat mengkonstruksi pemahamannya yang telah didapatkan dari eksplorasi tadi, sehingga kompetensi pengetahuan siswa akan menjadi lebih baik, serta pemahaman siswa terhadap pembe lajaran akan lebih mudah serta terkait dengan dunia nyata dan pengetahuan yang telah didapatkannya dari pengalaman. Tugas-tugas yang diberikan kepada sis wa merupakan tugas bermakna yang dapat melatih kompetensi pengetahuan siswa menjadi lebih baik.

Hasil terakhir yang dicapai adalah MPKA meningkatkan kompetensi keterampilan siswa. Peningkatan kompetensi keterampilan meliputi aspek mengamati, mengajukan pertanyaan, melaku kan penyelidikan, mengolah data dan menyimpulkan yang lebih baik dalam proses pembelajaran. Kesimpulan yang didapatkan model MPKA dapat meningkatkan kompetensi keterampilan.

Pelaksanaan praktikum yang ditunjang dengan Lembar Kerja Siswa (LKS) yang terintegrasi literasi didalamnya membuat siswa menjadi lebih antusias dalam melakukan praktikum. Kegiatan praktikum meningkatkan kompetensi keterampilan siswa dalam pembelajaran karena kompetensi keterampilan dapat menunjukkan tingkat keahlian siswa dalam suatu kegiatan atau tugas ${ }^{[14]}$. Kegiatan-kegiatan yang ditulis kan dengan jelas di dalam LKS memudahkan siswa untuk bekerja dalam kelompok dan mengikuti runtu tan cara kerja dalam LKS. Kemampuan siswa akan terlihat jelas karena dituntut untuk mencoba dan menalar dalam waktu bersamaan. Kemampuan meng amati, menulis, menghitung siswa juga menjadi lebih 
terlatih dan meningkat. Pada pelaksanaannya kegiatan praktikum ini akan dibimbing oleh guru yang nantinya akan dievaluasi dan disimpulkan bersama hasil yang telah dicobakan oleh siswa, sehingga akan terjalin komunikasi yang baik juga antara siswa dan guru.

MPKA ini direkomendasikan untuk di gunakan oleh guru IPA dikarenakan mengandung pembelajaran kontekstual, dan teori belajar konstruktivisme serta pembelajaran bermakna yang memudahkan guru dalam mengajarkan pembelajaran karena sintak yang digunakan serta sumber belajar yang digunakan dalam buku ini lebih dekat pada pengalaman siswa. Penerapan MPKA ini bagus untuk siswa karena pembelajaran yang dekat dengan kondisi nyata siswa, serta tugas-tugas bermakna yang dapat meningkatkan kompetensi siswa. Pembela jaran MPKA ini sudah memenuhi permintaan pendidikan abad ke-21.

Harapan untuk mendapatkan hasil yang sempurna tidak mudah untuk diwujudkan. Selama penelitian berlangsung, terdapat keterbatasan dan berbagai kendala. Hal ini yang menyebabkan hasil yang diinginkan tidak sempurna.

Keterbatasan pertama yaitu, penelitian dilaku kan hanya pada satu tema saja. Tindak lanjut penelitian ini, hendaknya tema yang digunakan ditambah lagi. Semakin bervariasi tema, semakin terlihat keterkaitan dan keterpaduan materi pembe lajaran yang ada serta penerapan Model Pembelajaran Kontekstual Adaptif ini menjadi lebih maksimal.

Keterbatasan kedua yaitu, tipe model yang digunakan hanyalah tipe model terjaring saja. Hal ini dikarenakan pembelajaran IPA menggunakan pende katan tematik. Solusinya adalah dengan mengguna kan tipe model lain yang disandingkan dengan model terjaring, karena pembelajaran IPA juga bisa dilak sanakan dengan menggunakan tipe model terintegrasi.

Keterbatasan terakhir yaitu bahan ajar yang digunakan adalah Buku Ajar IPA Terpadu yang mengintegrasikan literasi dan pembelajaran konteks tual didalamnya. Buku ajar ini masih perlu ditingkat kan lagi keterpaduannya, namun sebagian besar sudah menunjukkan keterpaduan. Agar tingkat keterpaduan nya menjadi lebih bagus lagi, perlu diadakannya revisi sehingga menjadikan buku ajar yang digunakan dapat lebih meningkatkan kualitas pembelajaran.

\section{Kesimpulan}

Berdasarkan analisis yang dilakukan didapat kan kesimpulan penelitian. Kesimpulan dari peneliti an ini adalah penerapan Model Pembelajaran Kontekstual Adaptif memberikan pengaruh yang berarti pada kompetensi sikap, pengetahuan dan keterampilan IPA siswa pada taraf signifikan $95 \%$. Oleh karena itu, penerapan Model pembelajaran ini efektif diterapkan pada tema gerak dalam kehidupan kelas VIII SMPN 13 Padang.

\section{DAFTAR PUSTAKA}

[1] Jennifer Nichols. 2013. 4 Essensial Rules of 21st Century Learning.

[2] Menteri Pendidikan dan Kebudayaan RI Nomor 58 tahun 2014 tentang Kurikulum 2013 Seko lah Menengah Pertama/Madrasah Tsanawiyah Jakarta : Depdiknas

[3] Putri Dwi Sari, Asrizal, Letmi Dwiridal. 2017. Pengembangan LKS IPA Terpadu Kontekstual Bermuatan Literasi Tema Pemanfaatan Tekanan Dalam Kehidupan Untuk Pembe lajaran Siswa Smp Kelas VIII. Pilar Of Physics Education Jurnal Berkala Ilmiah Pendidikan Fisika. Vol 10, Tahun V. 89-96

[4] Fahmiati. 201. Peningkatan Hasil Belajar IPA Terpadu Melalui Model Pembelajaran Konteks tual. Jurnal Nalar Pendidikan UNM. Vol 2, No 2, $219-221$

[5] Tukiran Taniredja, Efi Miftah Faridli \& Sri Harmianto. 2012. Model-Model Pembelajaran Inovatif. Bandung : CV ALFABETA

[6] Trianto. 2012. Model Pembelajaran Terpadu. Jakarta:Bumi Aksara.

[7] Asrizal. 2017. Model Pembelajaran Kontekstual Adaptif. Padang: FMIPA UNP

[8] Asrizal, Ali Amran, Azwar Ananda dan Festiyed. 2017. Effectiveness of Adaptive Contextual Learning Model of Integrated Science by Integrating Digital Age Literacy on Grade VIII Students. IOP. Conf. Series: Materials Science and Engineering 335.

[9] Setya Nurachmandani \& Samson Samsulhadi. 2010. Ilmu Pengetahuan Alam 2 (Terpadu) Untuk SMP dan MTs Kelas VIII. Jakarta: Pusat Perbukuan, Kementerian Pendidikan Nasional.

[10] Saeful Karim,dkk. 2008. Belajar IPA Membuka Cakrawala Alam Sekitar untuk Kelas VIII Sekolah Menengah Pertama/Madrasah Tsana wiyah. Jakarta: Pusat Perbukuan, Departemen Pendidikan Nasional,

[11] Wasis \& Sugeng Yuli Irianto. 2008. Ilmu Pengetahuan Alam untuk SMP dan MTs Kelas VIII. Jakarta: Pusat Perbukuan, Depdiknas.

[12] Asrizal, Ali Amran, Azwar Ananda, Festiyed, Suci Khairani. 2018. Effectiveness of Integrated Science Instructional Material on Pressure in Daily Life Theme to Improve Digital Age Literacy of Students. IOP Conf. Series: Journal of Physics: Conf. Series 1006

[13] Trianto Ibnu Badar Al-Tababy.2014. Mendesain Model Pembelajaran Inovatif, Progresif dan Kontekstual (Konsep, Landasan dan Implementasinya Pada Kurikulum 2013). Jakarta: Kencana Prenadamedia Group

[14] Kunandar. 2013. Penilaian Auntentik Penilai an hasil Belajar Siswa Berdasarkan K-2013) Suatu pendekatan Praktis Disertai Contoh. Jakarta: PT raja Grafindo Persada. 